\title{
Hypochlorite Generation from a Water Softener Spent Brine
}

\author{
Daniela Sánchez-Aldana ${ }^{1,2}$ (1) , Noe Ortega-Corral ${ }^{3, *}$, Beatriz A. Rocha-Gutiérrez ${ }^{2}$, \\ Lourdes Ballinas-Casarrubias ${ }^{2, *}$, Eneidy J. Pérez-Domínguez ${ }^{2}$,

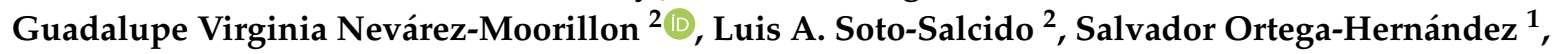 \\ Guadalupe Cardenas-Félix ${ }^{1}$ and Guillermo González-Sánchez ${ }^{4}$ \\ 1 Centro de Desarrollo e Innovación Tecnológica, Industrializadora de Cárnicos Strattega S.A. de C.V. Km. 7.5 \\ Carretera a Cuauhtémoc, Colonia Las Ánimas, Chihuahua 31450, Mexico; dsanchez@bafar.com.mx (D.S.-A.); \\ sortega@bafar.com.mx (S.O.-H.); gcardenas@bafar.com.mx (G.C.-F.) \\ 2 Facultad de Ciencias Químicas, Universidad Autónoma de Chihuahua, Chihuahua 31124, Mexico; \\ brocha@uach.mx (B.A.R.-G.); mitigandae.e@gmail.com (E.J.P.-D.); vnevare@uach.mx (G.V.N.-M.); \\ p185949@uach.mx (L.A.S.-S.) \\ 3 Festa-Hidrogel S. A. de C.V. República de Colombia No. 219 Col Panamericana, Chihuahua, \\ Chihuahua C.P. 31107, Mexico \\ 4 Centro de Investigación en Materiales Avanzados, S.C. Miguel de Cervantes 120, Complejo Industrial \\ Chihuahua, Chihuahua 31136, Mexico; guillermo.gonzalez@cimav.edu.mx \\ * Correspondence: Filtrosyequipos2014@gmail.com (N.O.-C.); mballinas@uach.mx (L.B.-C.); \\ Tel.: +52-614-236-6000
}

Received: 13 September 2018; Accepted: 1 November 2018; Published: 26 November 2018

\begin{abstract}
Industries that require water with low hardness consume large amounts of $\mathrm{NaCl}$ for water softening. In this work, water softener spent brines were recovered and used as raw material in an electrolysis cell with cationic exchange membrane (CEM) to yield both sodium hypochlorite and sodium hydroxide amounts, which are the most common disinfectants used to sanitize production areas. Spent brines contained mainly an average of $4.5 \% \mathrm{NaCl}, 650 \mathrm{mg} \mathrm{L}^{-1} \mathrm{Ca}^{2+}$, and $110 \mathrm{mg} \mathrm{L}^{-1}$ $\mathrm{Mg}^{2+}$, the last two cations adversely affect the CEM and must be treated prior to the electrolytic process. Two hardness removal methods were evaluated separately-lime-soda ash and sodium hydroxide-soda ash softening - the last one being the most effective as total hardness was decreased by $99.98 \%$. This pretreated spent brine was then introduced into the electrolysis cell. Experimental design comprised five level variations for current intensity, $\% \mathrm{NaCl}$, and time. The best operation conditions yielded $2800 \mathrm{mg} \mathrm{L}^{-1} \mathrm{NaOCl}$ for a $5 \% \mathrm{NaCl}$ solution. By incorporating chlorine gas trap to increase $\mathrm{OCl}^{-}$concentration a maximum of $7400 \mathrm{mg} \mathrm{L}^{-1} \mathrm{NaOCl}$ was achieved. Finally, biocidal activity was tested following sanitation protocols ( $\mathrm{NaOCl}$ dilution level) on workbenches and a decrease in bacterial count of at least 5 logs under laboratory-controlled conditions.
\end{abstract}

Keywords: water re-use; spent brine; membrane processes

\section{Introduction}

One of the biggest challenges in the meat industry is the control of microorganisms and pathogens that could be present throughout meat processing. Microorganisms and pathogens grow forming predominantly biofilms, which allow bacteria to adhere to different surfaces and structures that are in contact with the food, colonizing them rapidly [1,2]. One of the most effective treatments to eliminate these pathogens is to use chlorine derivatives in combination with other sanitizers in alkaline or acid solutions [3,4]. Sodium hypochlorite is commonly used to disinfect areas against bacteria, spores, yeasts, molds, bacteriophages, and some viruses. It is considered very effective against Gram-negative 
bacteria. Chlorine damages the cell membrane causing its disruption, and therefore inactivates bacteria growth $[5,6]$. Alkali compounds such as sodium hydroxide $(\mathrm{NaOH})$ are also commonly used in the food industry to clean surfaces that will be in contact with raw food. It has been reported that Pseudomonas putida [7], Salmonella [8], E. coli O157:H7 [9], and Monocytogenes [10] are more efficiently inactivated by combining sodium hypochlorite and alkali solutions.

The electrolysis of sodium chloride $(\mathrm{NaCl})$ for hypochlorite production has been documented since the last century [11]. In patent US7931795B2, a process for on-site chlorine and high strength sodium hypochlorite production was documented. The system was able to generate chloride gas and $\mathrm{NaOH}$ in combination; 5 to $100 \%$ of the total chlorine produced by the process can be converted to high strength bleach and produce $2-15 \%$ of $\mathrm{NaOCl}$ [12]. In the same patent it was reported that chlorine and aqueous alkali metal hydroxide can be produced in electrolytic cells filled with brine. Rojas and coworkers (2002) evaluated commercial equipment for sodium hypochlorite $(\mathrm{NaOCl})$ production; they concluded that the quality of the brine is highly important for the adequate operation of the electrolytic process [13]. The use of concentrated media of $\mathrm{NaCl}$ has been also tested for sea water. Asokan (2009) designed an electrolytic cell where precipitated salts were removed using hydrochloric acid [14].

Commercial electrolytic cells commonly used for sodium hypochlorite production are composed of two electrodes: a cathode which is generally composed of 316 stainless steel and an anode which is an inert material such as titanium with a platinum layer, because of its high oxidation tolerance [11]. Both electrodes are submerged in a solution composed of $\mathrm{NaCl}$ under the influence of a voltage. The principle of an electrolytic cell is based on the electrolysis reactions that occurred at the electrodes when a voltage is applied. In a $\mathrm{NaCl}$ solution, the following ions are present, sodium $\left(\mathrm{Na}^{+}\right)$, chloride $\left(\mathrm{Cl}^{-}\right)$, hydrogen $\left(\mathrm{H}^{+}\right)$, and hydroxyl $\left(\mathrm{OH}^{-}\right)$ions from water dissociation. At the positive electrode (anode) the chloride ions are oxidized by yielding an electron, thus giving up chlorine gas $\left(\mathrm{Cl}_{2}\right)$. At the negative electrode (cathode) the hydrogen ion $\left(\mathrm{H}^{+}\right)$is reduced forming hydrogen $\left(\mathrm{H}_{2}\right)$. In the water, the remaining $\mathrm{Na}^{+}$ions and $\mathrm{OH}^{-}$ions form a solution of sodium hydroxide $(\mathrm{NaOH})$. The dissolved $\mathrm{Cl}_{2}$ obtained at the anode cannot be recovered because it reacts immediately with the $\mathrm{NaOH}$ to form sodium hypochlorite $(\mathrm{NaOCl})$, sodium chloride, and water, all of which are dissociated in solution. For an efficient disinfection processes, a minimum hypochlorite concentration of $5 \%$ by volume is required. Directly from the brine electrolysis, a $0.8 \%$ concentration of $\mathrm{NaOCl}$ is obtained [15]. In order to produce an unpolluted and more concentrated solution of hypochlorite, it is necessary to separate the cell from each electrode by a semipermeable barrier such as an ion exchange membrane [16,17].

In this work, a lab-scale electrolytic cell was used as an on-site system for the generation of sodium hypochlorite and sodium hydroxide to be employed during the cleaning and disinfection processes in the meat industry. To the best of the author's knowledge, this is the first work using softener spent brine that is reused to feed an electrolytic cell and produce useful disinfectants. Different electrolytic configurations for $\mathrm{NaOCl}$ and $\mathrm{NaOH}$ production and spent brine treatments were evaluated; the experiments were carried out using a cationic exchange membrane (CEM) in an experimental design comprised of three level variations of voltage, salt percentage, and time. The dependency of the configuration on the hypochlorite production was assessed. Finally, biocidal activity was tested following regulated sanitation protocols ( $\mathrm{NaOCl}$ dilution level) on workbenches and bacterial cultures.

\section{Materials and Methods}

\subsection{Test Site}

The water softener spent brine used as the raw material for the electrolytic cell for this work was collected from one of the biggest meat industries in Mexico, Grupo Bafar located at Chihuahua, Chihuahua, Mexico. Currently, this industry consumes around $400 \mathrm{~kg}$ of industrial salt per day to regenerate the cationic resins used in water softeners to treat the water used in the process. As a 
consequence, a high concentration of spent brine rich in $\mathrm{Na}^{+}, \mathrm{Cl}^{-}, \mathrm{Ca}^{2+}$, and $\mathrm{Mg}^{2+}$ is directly discharged into the sewer.

This spent brine could be directly used in the electrolytic cell to generate two commonly used disinfectant products in the meat industry such as sodium hypochlorite and $\mathrm{NaOH}$. However, $\mathrm{Ca}^{2+}$, $\mathrm{Mg}^{2+}$, as well as bicarbonates, at high $\mathrm{pH}$ in the electrolytic cell, are easily converted to calcium carbonate $\left(\mathrm{CaCO}_{3}\right)$ and magnesium hydroxide. These compounds are highly insoluble, and constitute precipitates at the anode and in the chamber. For this reason, it is necessary to previously remove the precipitable ions by adding sodium carbonate or sodium hydroxide [18].

\subsection{Spent Brine Characterization from the Softening System}

Samples were taken directly from the water softening discharge. The softening system features a twin configuration with a Logix 764 programmable control valves model 293 Magnum IT (Milwaukee, WI, USA). This softening system was regenerated every $4 \mathrm{~h}$ with a concentrated saline solution stored in a plastic tank. The softening program consists of a 3-step process: backwash (14 min), resin regeneration $(50 \mathrm{~min}$ ), and rinse $(6 \mathrm{~min})$ (see Figure 1). According to preliminary characterization, step 3 (rinsing) was considered as the optimum stage for operation recovering the spent brine and treating it prior to using it in the electrolytic cell. The samples for the electrolysis experiments of spent brine were taken, thus in this step the total volume was $30 \mathrm{~L}$.

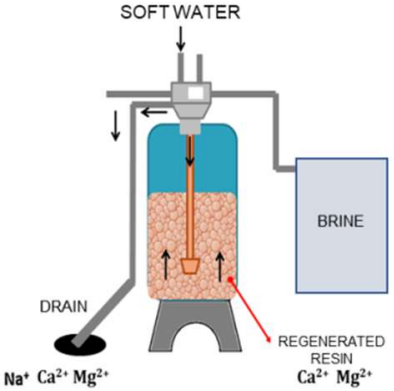

(a)

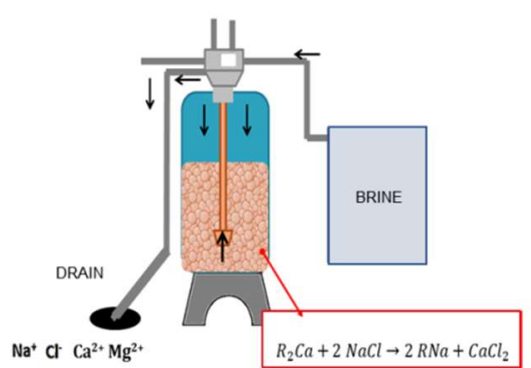

(b)

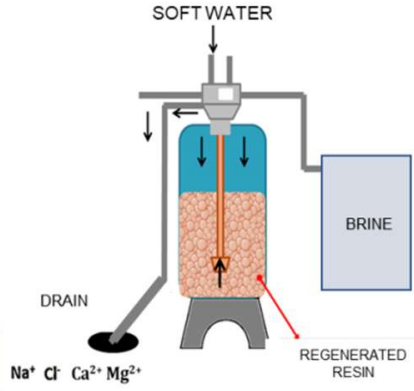

(c)

Figure 1. Spent brine generation. The softening program consists of a 3-step process: (a) A backwash (14 $\mathrm{min}$ ) where fresh water is introduced to the resin from the bottom to the top; (b) resin regeneration (50 $\mathrm{min}$ ) where a brine solution is used to liberate calcium and magnesium from the resin and generate de sodic character; and (c) rinse $(6 \mathrm{~min})$ to liberate the residual sodium chloride, calcium, and magnesium.

Spent brine samples were collected from step 3 and ions contents were characterized according to their total hardness (NMX-AA-072-SCFI-2001), alkalinity (NMX-AA-036-SCFI-2001), calcium hardness (NMX-AA-073-SCFI-2001), and chloride (NMX-AA-072-SCFI-2001) content.

\subsubsection{Total Hardness}

Samples of $20 \mathrm{~mL}$ of spent brine were taken in triplicate. Each sample was diluted and adjusted at pH 7 with a solution of ammonium chloride (Analytical grade, CTR, Nuevo León, Mexico). A titrimetric procedure was made using $2 \mathrm{~g}$ of black eriochrome $\mathrm{T}$ (Analytical grade, CTR, Nuevo León, Mexico) and titrated with EDTA 0.01 M (HYCEL, Nuevo León, Mexico).

\subsubsection{Alkalinity}

A titrimetric procedure was followed using $100 \mathrm{~mL}$ of brine and titrated with $\mathrm{HCl} 0.02 \mathrm{~N}$ (Analytical grade, CTR, Nuevo León, Mexico) in the presence of Phenolphthalein (Fermont, Monterrey, Mexico). 


\subsubsection{Calcium Hardness}

$50 \mathrm{~mL}$ of test sample were taken and the $\mathrm{pH}$ was adjusted between 12 and 13 with sodium hydroxide (Analytical grade, CTR, Nuevo León, Mexico). Calcium was titrated with EDTA (Hycel, Nuevo León, Mexico) using murexide (Analytical grade, CTR, Nuevo León, Mexico) as visual indicator.

\subsubsection{Chlorides}

One-hundred milliliters of brine was taken and the $\mathrm{pH}$ was adjusted at 7. 10-milliliters of potassium chromate (Analytical grade, CTR, Nuevo León, Mexico) was added and titrated with $0.1 \mathrm{M}$ silver nitrate (Analytical grade, CTR, Nuevo León, Mexico) until it turned from green to yellow.

\subsection{Pretreatment}

The brine hardness was decreased using the following procedure. The amount of $\mathrm{NaOH}$ and $\mathrm{Na}_{2} \mathrm{CO}_{3}$ per liter was determined stoichiometrically based on the performed characterization of alkalinity and hardness. The reagents were put in contact with one liter of brine, and stirred magnetically at $120 \mathrm{rpm}$ for $130 \mathrm{~min}$. The spent brine was filtered using Whatman ${ }^{\circledR}$ qualitative filter paper No. 2. The final concentration of calcium and magnesium was determined after the precipitation pretreatment. The $\mathrm{pH}$ was adjusted to 7 using $\mathrm{HCl} 36 \%$ (Analytical grade, CTR, Nuevo León, Mexico).

Then, the treated spent brine was filtered through a system of 3 filters of 50, 25, and 1 micron and then treated with an ion exchange chelating resin Purolite 9940 to reduce $\mathrm{Ca}^{2+}$ and $\mathrm{Mg}^{2+}$ trace concentration that could affect the electrolytic cell. The chloride concentration in the real brine was adjusted to $5 \%$ by adding $\mathrm{NaCl}$ (Sales of Itsmo S.A. de C.V.,Veracruz, Mexico).

\subsection{Treatment in the Electrolytic Cell}

A chlor-alkali electrolytic system BED1-2 Smart Disinfection lab/piloting unit with a PcCell (Mod. 62/124, Heusweiler, Germany), was used to obtain sodium hypochlorite and sodium hydroxide. The electrolysis cell is a commercially available system mounted in a skid with an integrated HMI and data acquisition system. The electrolysis system consisted of an anode and cathode chambers and a membrane in between with an effective area of $124 \mathrm{~cm}^{2}$. The cell frame was made of PVC, the electrodes: anode of titanium with Pt coating and the Cathode stainless steel. The separator is a PC SepMR 5483 (PcCell, Heusweiler, Germany) and a space of $1.5 \mathrm{~cm}$ between the electrode. The system contained on-line conductivity meters (Jumo CTI-500, Heusweiler, Germany) and flowmeters to monitor the electrical conductivity and flows, respectively. The electrolysis unit was powered by a direct current power supply, with maximum amperage of $24 \pm 1$ A (Mantec, HCS-3200). The flow rate in the anolyte could be up to $50 \mathrm{~L} \mathrm{~h}^{-1}$, and the flow rate in the catholyte of ca $25 \mathrm{~L} \mathrm{~h}^{-1}$. The temperature was monitored directly and controlled in the feed and reception tanks with digital thermometers. It is important to state that separator failed at temperatures higher than $40{ }^{\circ} \mathrm{C}$. The $\mathrm{pH}$ of the anolyte and catholyte was measured with a pH-meter Orion3-Star Plus Benchtop (ThermoElectron Co., Pittsburgh, PA, USA) inserted into the reception tanks. The membrane used was the PC MF (PCcell, Heusweiler, Germany). The gases produced in the electrolytic process were vented using a ventilation hood. Current, voltage, free chlorine, sodium hydroxide, temperature, and $\mathrm{pH}$ were measured throughout all the experiments.

Initial experiments were held using synthetic brines with $3 \%, 5 \%, 10 \%, 15 \%$, and $39 \% \mathrm{NaCl}$ concentrations, applying 16, 20, and $24 \mathrm{~A}$, with a total of 40 experiments for the initial screening. The best operational set up for hypochlorite production was as follows, a flow of $10 \mathrm{~L} \mathrm{~h}^{-1}$ in the anolyte and catholyte and a temperature of $33 \pm 3^{\circ} \mathrm{C}$. Sampling was made at different time of operation of the cell (0-240 $\mathrm{min})$. Once the system was assessed in terms of voltage and salt concentration for hypochlorite production, the following configurations (2.4.1-2.4.3) were evaluated, using the pretreated rejection brine. Anolyte and catholyte fluxes were set at $10 \mathrm{~L} \mathrm{~h}^{-1}$ throughout the tests assessed. 


\subsubsection{Regular Process}

The initial set up was in the normal regular process (Figure 2a) the pretreated rejection brine was injected into the cell and $\mathrm{NaOCl}$ and $\mathrm{NaOH}$ samples were collected in separate tanks. $\mathrm{NaOH}$ was obtained in the cathode and $\mathrm{NaOCl}$ in the anode. Current, voltage, free chlorine, sodium hydroxide, temperature, and $\mathrm{pH}$ were measured throughout the test.

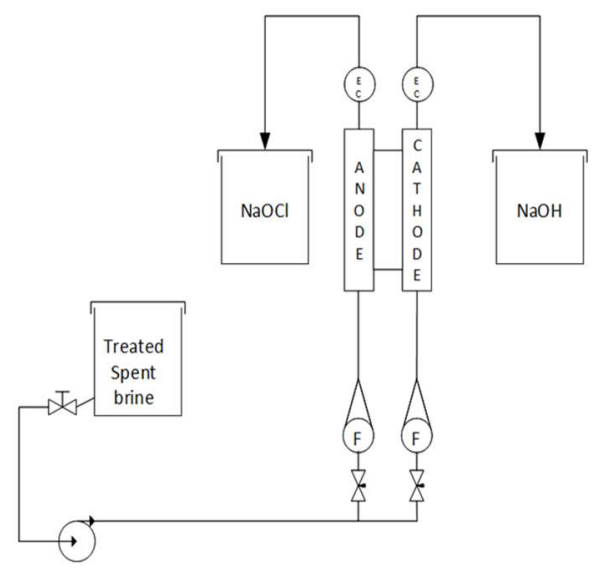

(a)

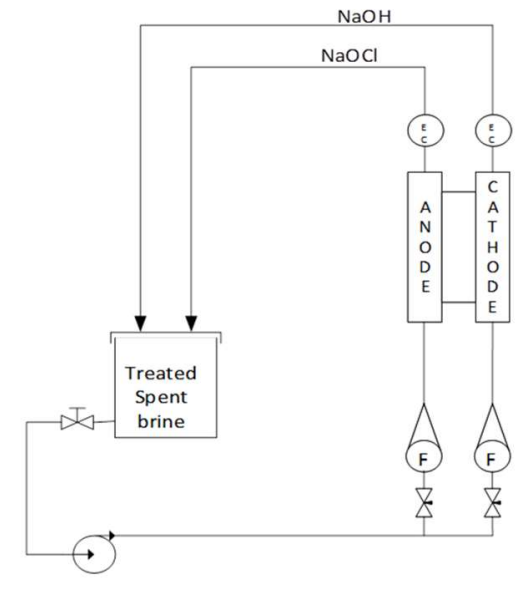

(b)

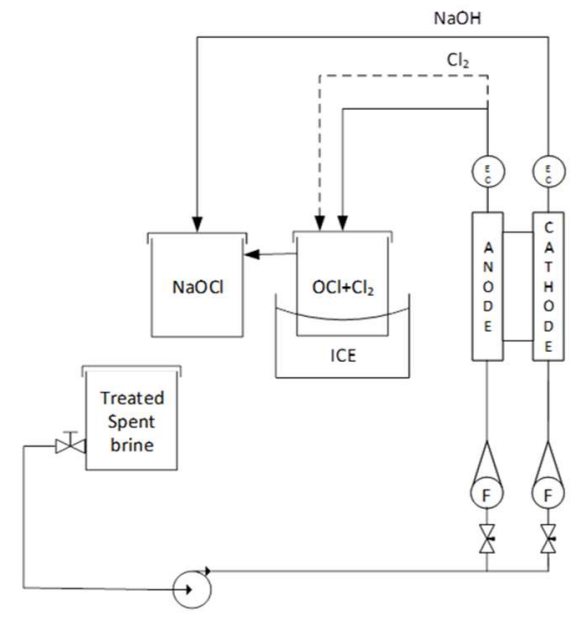

(c)

Figure 2. Spent brine treatments. (a) Regular process: the spent brine is fed to the cell and the $\mathrm{NaOCl}$ and $\mathrm{NaOH}$ are were collected in separate tanks. (b) Recirculation process: the spent brine is initially pumped to the electrolytic cell; afterwards, the obtained $\mathrm{NaOCl}$, as well as the unreacted $\mathrm{NaCl}$, are recirculated back to the holding tank and repumped to the cell for a fixed time and flowrate. (c) Bubbling process: the brine is pumped into the cell and the obtained $\mathrm{NaOCl}$ is conducted to a cooled container with the objective of separate the chloride water and the gas. The resulting gas is further injected into other container and put in contact with $\mathrm{NaOH}$ solution.

\subsubsection{Recirculation Process}

In the recirculation process (Figure $2 b$ ) pretreated rejection brine was injected into the electrolytic cell, the $\mathrm{NaOH}$ and $\mathrm{NaOCl}$ outlets were both connected to the brine tank and the process was recirculated for $4 \mathrm{~h}$. The same variables were monitored as 2.4.1. 


\subsubsection{Bubbling Process}

In the bubbling process the pretreated brine was injected into the electrolytic cell, the $\mathrm{NaOCl}$ outlet was then connected to a cold tank in order to separate the chlorinated water and the gas, and this resulting gas was injected into a tank in the presence of a $\mathrm{NaOH}$ solution, mixed, and recirculated (Figure 2c).

\subsection{Hypochlorite Determination}

The determination of sodium hypochlorite was performed following the method NMX-AA-124-SCFI-2006. In a $300 \mathrm{~mL}$ volumetric flask, $1 \mathrm{~mL}$ of the sample was poured and closed it immediately. Approximately 2 or $3 \mathrm{~g}$ of potassium iodide was weighed and added with $3 \mathrm{~mL}$ of concentrated glacial acetic acid; the flask was closed and left to stand for $5 \mathrm{~min}$ in the dark. After this time the solution was titrated with sodium thiosulfate solution.

\subsection{Determination Sodium Hydroxide}

The content of $\mathrm{NaOH}$ was calculated by a titrimetric method using potassium biphthalate as the primary standard, dissolved previously in $\mathrm{CO}_{2}$ free water. The equivalence point was determined using phenolphthalein (Hycel, Nuevo León, Mexico).

\subsection{Disinfection Capability}

Microbiological analyses were carried out with the aim to evaluate the effectiveness of the $\mathrm{NaOCl}$ solution obtained in the electrolytic cell from the rejection brine solution. The microbial challenge methodology was used to determine the disinfection capacity against five microbial strains that were isolated from the processing plant. A bacterial suspension of $8.0 \log \mathrm{UFC} \mathrm{mL}^{-1}$ was prepared in $\mathrm{NaCl}$ $0.85 \%(w / v) ; 1 \mathrm{~mL}$ from this suspension was added to the working $\mathrm{NaOCl}$ solution and incubated. After a one min of contact, the suspension was further diluted in decimal dilutions to obtain the total mesophilic counts (NOM-092-SSA1-1994). In order to test the $\mathrm{NaOCl}$ solution under working conditions, microbial counts for total mesophilic counts (NOM-092-SSA1-1994), total coliforms as well as E. coli (NOM-113-SSA1-1994) were obtained from processing surfaces before and after application of the brine solution. Results are expressed as reductions in microbial counts (Log reduction). Samples of $\mathrm{NaOCl}$ were diluted to $400 \mathrm{mg} \mathrm{L}^{-1}$ as control; commercial $\mathrm{NaOCl}$ (Cloralex, Nuevo León, Mexico, $13 \% w / v)$ was used at $400 \mathrm{mg} \mathrm{L}^{-1}$ also.

\subsection{Preliminary Economic Evaluation}

An economic evaluation was made for hyplochlorite production. It was realized to determine the economic feasibility of implementing the technology in the plant. The approach used was chosen with the intention of considering the full integrated manufacture train, incorporating the operational strategies.

\section{Results and Discussion}

\subsection{Spent Brine Characterization and Pretreatment}

The principal focus of this work is to reuse the pretreated rejection brine produced in the water softening process in order to reduce the environmental impact and generate an alternative process to produce inwards the disinfectants needed for sanitization. The spent brine ( $>3000 \mathrm{~L}$ per day) after pretreatment could be used as feedstock for the generation of disinfectants using an electrolytic process which is environmentally friendly, sustainable, and cost-effective.

It is widely known that in the alkali-chlorine generation process the brine quality is the main factor in achieving an efficient process. The challenge of this process was to treat spent brine with high concentrations mainly of calcium, magnesium, sulfate, and alkalinity. The brine generated at stage 3 
presented an average amount of $2.7 \%$ of sodium chloride (Figure 1 ) and was characterized in terms of calcium, magnesium, and total hardness. The relation among the principal ions responsible for the hardness and $\mathrm{NaCl}$ content are evidenced in Figure 3. The requirements needed for $\mathrm{EC}$ process are $250 \mathrm{~g} \mathrm{~kg}^{-1}$ for $\mathrm{NaCl}$, and less of $30 \mu \mathrm{g} \mathrm{L}^{-1}$ of calcium and magnesium principally $[19,20]$.

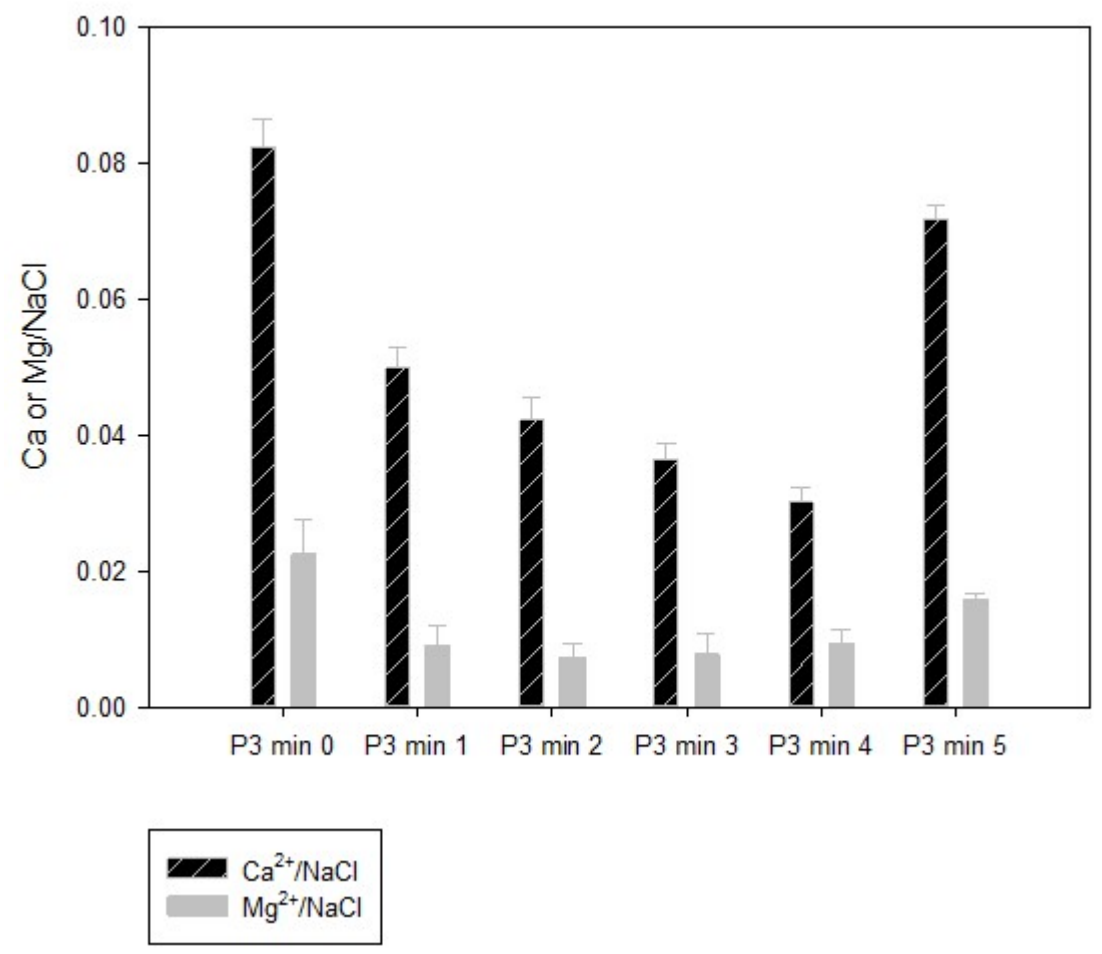

Figure 3. Calcium and magnesium relation to $\mathrm{NaCl}$ in the softener water (P3: step 3 of the spent brine generation).

In this work, the available $\mathrm{NaCl}$ in the spent brine was of $2.7 \%$ with a ratio of $\mathrm{Ca}^{2+}: \mathrm{NaCl}$ up to 0.08 (Figure 3), for that reason, two different chemical precipitation processes were tested: (1) Lime-soda ash and (2) sodium hydroxide-soda ash; the latter being the most effective method, reducing carbonate and noncarbonate hardness by $99.46 \%$.

Trace concentrations of $\mathrm{Ca}^{2+}$ and $\mathrm{Mg}^{2+}$ are undesirable in the spent brine, because they will eventually foul the cation exchange membrane; for that reason a chelating resin was used to remove the precipitable ions, attaining $99.98 \%$ total hardness removal.

\subsection{Treatment in the Electrolytic Cell}

In order to evaluate the electrolytic cell performance an initial screening of the operation voltage and hypochlorite production was made. The results of the evaluation made are depicted as a surface response using the software Sigma plot $13.0^{\circledR}$. The 3D graph of the variation of salt concentration and time in terms of voltage are shown in Figure 4. 

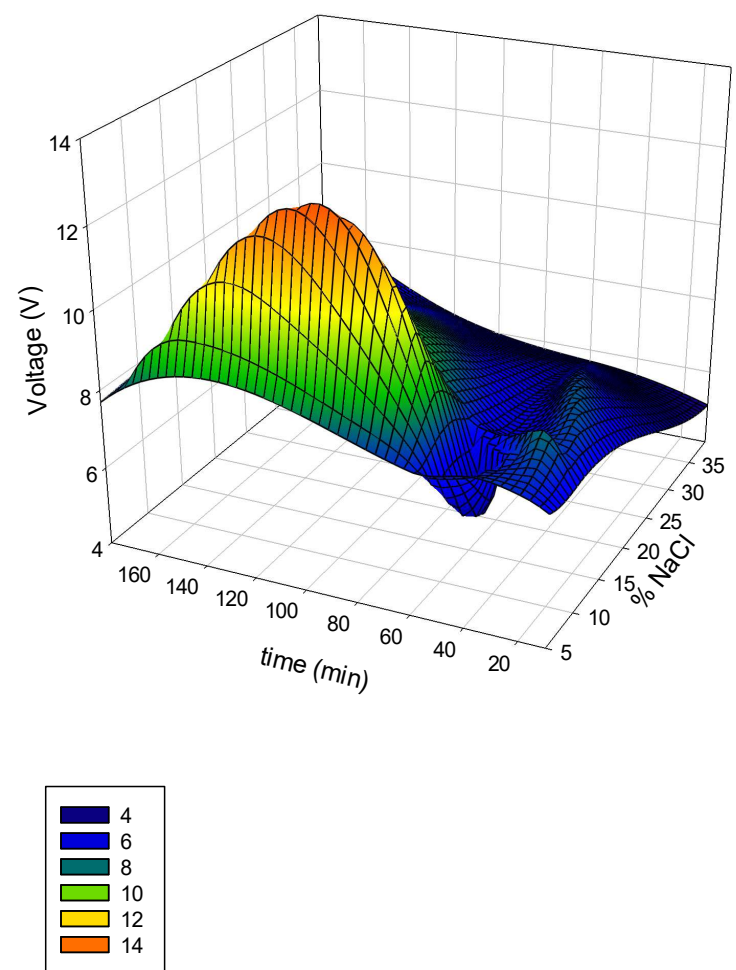

Figure 4. Voltage variation as a function of time and $\% \mathrm{NaCl}$ in the initial screening.

The results on hypochlorite production following the same variables were evidenced in Figure 5.

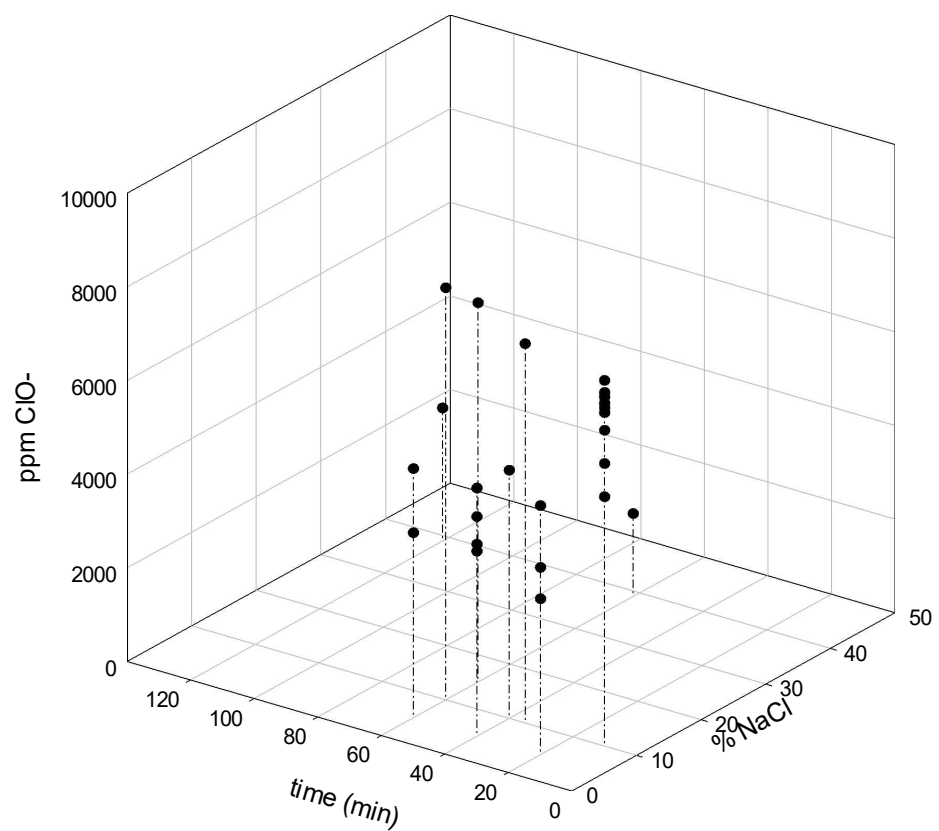

Figure 5. Hypochlorite production as a function of time and $\% \mathrm{NaCl}$ in the initial screening.

Finally, current density calculated as a function of voltage and current is shown graphically in Figure 6. 


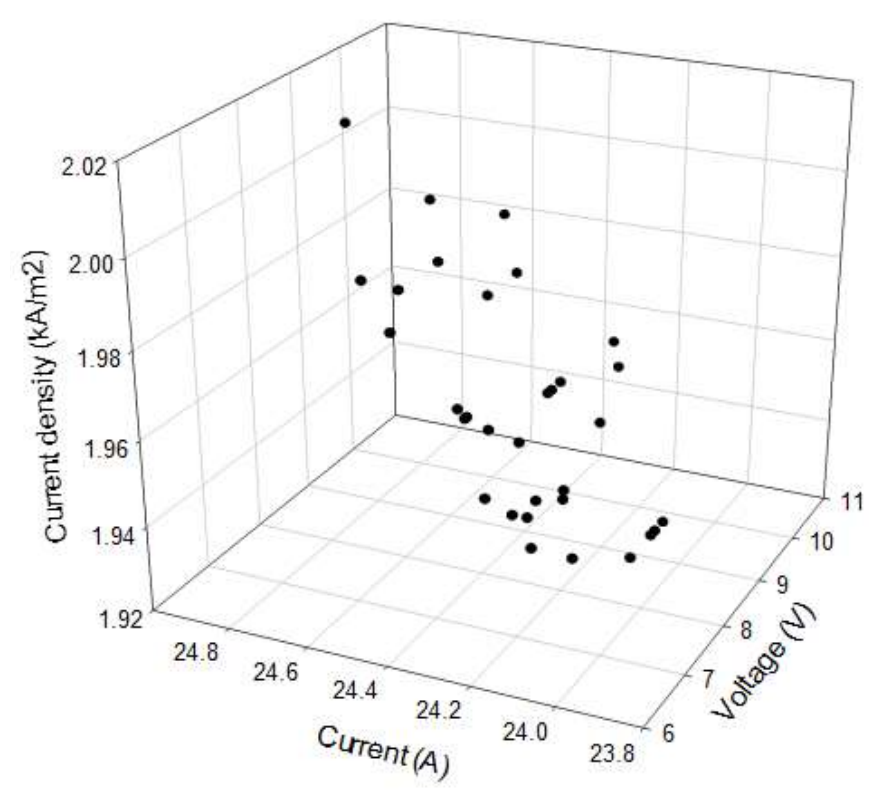

Figure 6. Current density as a function of current and voltage.

The treated spent brine was tested in three different experimental set ups: (1) Continuous (Regular process), (2) Recirculation, and (3) Bubbling, as previously described in Figure 2.

Based on the results found during the cell screening, the following variables were set, anode and cathode fluxes at $10 \mathrm{~L} \mathrm{~h}^{-1} ; \mathrm{NaCl}$ concentration of the brine was fixed at $5 \%$ for comparative purposes.

The normal process results are shown in Figure 7. The experimental conditions were set to have the treated spent brine pumped to the cell at a flow of $10 \mathrm{~L} \mathrm{~h}^{-1}$. A voltage of $9.7 \mathrm{VDC}$ and a current of $24 \mathrm{~A}$ was applied for a period of $240 \mathrm{~min}$. The obtained $\mathrm{NaOCl}$ was in average of $2150 \mathrm{mg} \mathrm{L}^{-1}$. The maximum concentration was attained at a short EC time $(30 \mathrm{~min})$. The obtained chlorine was mostly hypochlorous acid $(\mathrm{HClO})$ due to the $\mathrm{pH}$ of 2 which is known in the literature to be a more aggressive oxidizing agent.

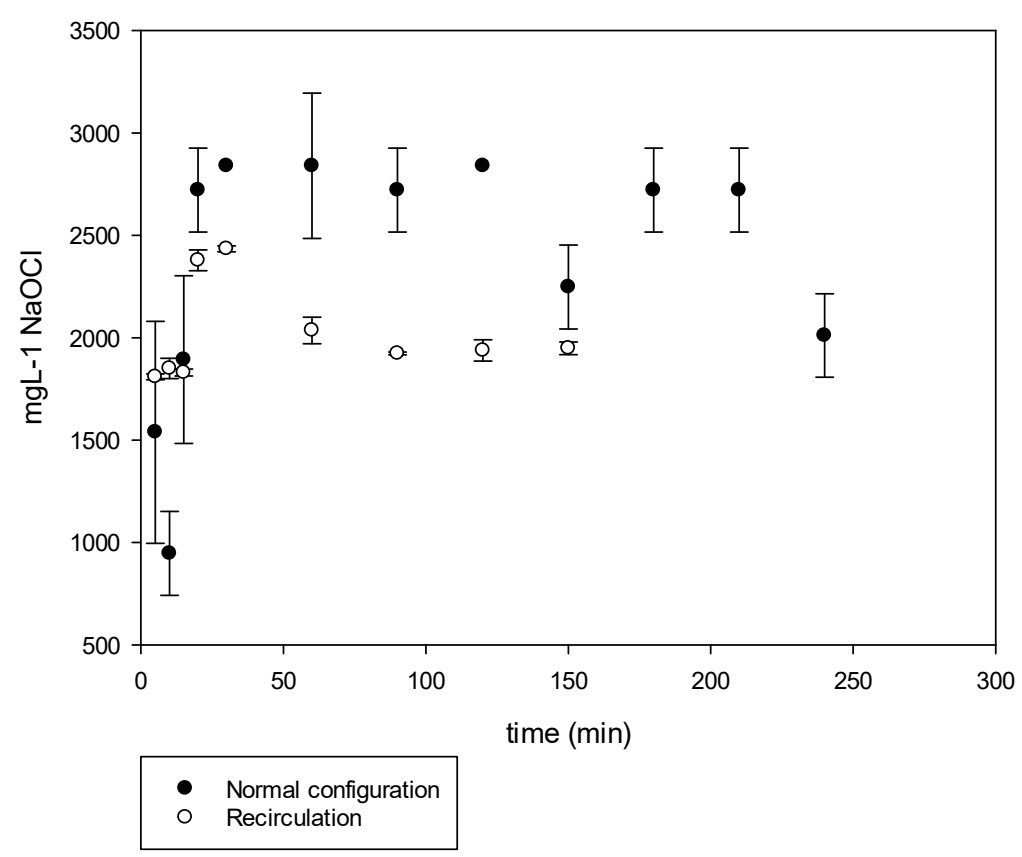

Figure 7. Hypochlorite production in normal and recirculation configuration. 
The results regarding alkali production are shown in Figure 8. The concentration of sodium hydroxide obtained was of $0.13 \mathrm{~N}$, the maximum concentration was attained at higher production time (90 $\mathrm{min}$ ) compared to hypochlorite production; corresponding to $0.52 \% w / v$. The reported values for a regular process are approximately 30 to $33 \%$ of $\mathrm{NaOH}$ [21]. Based on current technology, the highest concentration of sodium hydroxide that can be produced in the membrane electrolyzer is 35\% [22]. The commercial chlorine had a residue of $\mathrm{NaCl}$ which did not react in the electrolytic cell, for this reason and to maximize the available $\mathrm{NaCl}$, a second set of experiments was performed by recirculating the obtained $\mathrm{NaOCl}$ and $\mathrm{NaOH}$ back to the spent brine tank $[23,24]$. This proposal was based in the new established issues with regards to reduce water consumption [25]. During brine recirculation the depleted brine from the electrolysis cells was resaturated. This saturated brine could be fed back to the process. Recycling is a common practice in membrane cells; recycling is also used to reduce the temperature and concentration gradients. Also, it is used to reduce oxygen content and it is more acceptable for its use on site [21].

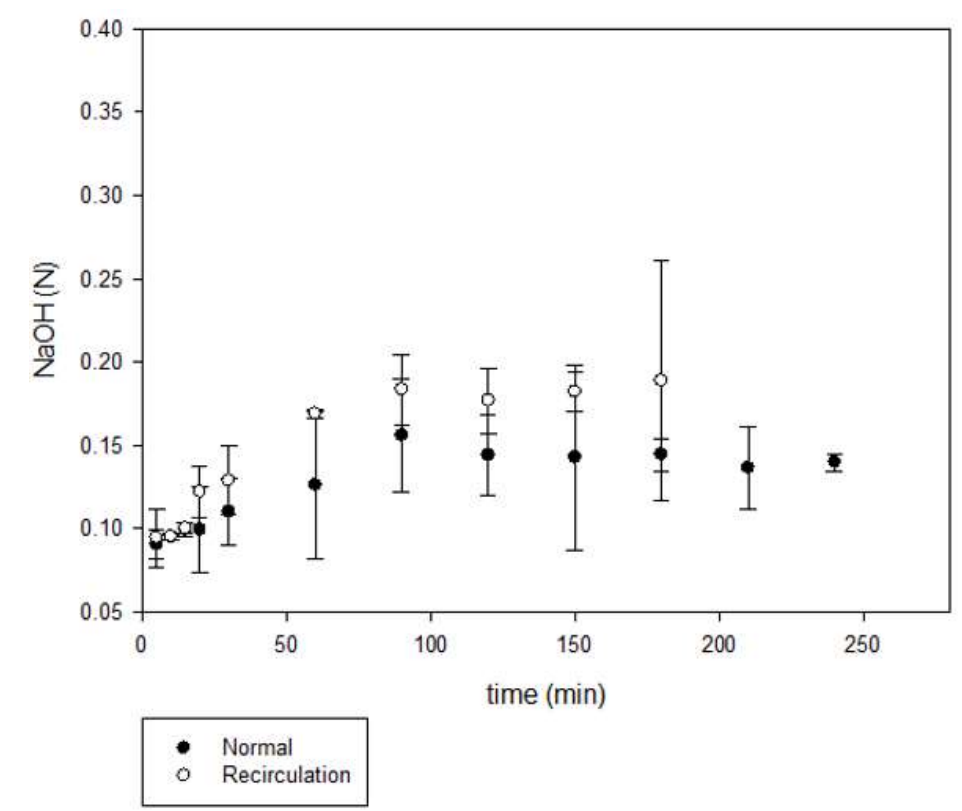

Figure 8. Hydroxide production in normal and recirculation configuration.

The operational conditions were similar to the initial set of experiments. However, the resulted $\mathrm{NaOCl}$ obtained was $2000 \mathrm{mg} \mathrm{L}^{-1}$, the $\mathrm{NaOH}$ was mixed in the spent brine tank. Since the $\mathrm{pH}$ was close to 10 , the main species was $\mathrm{NaOCl}$ (Figure 7).

In order to obtain higher concentrations of $\mathrm{NaOCl}$, a third set of experiments was performed. Similar operational conditions as the two-previous set of experiments were established; however, the hydraulics was modified to recover chlorine in gas $\left(\mathrm{Cl}_{2}\right)$ and bubble it back to the solution. The $\mathrm{NaOCl}$ and $\mathrm{NaOH}$ were diverted back to the spent brine and recirculated. With this experimental set, a total concentration of $\mathrm{NaOCl}$ of $7400 \mathrm{mg} \mathrm{L}^{-1}$ was obtained (Figure 9). 


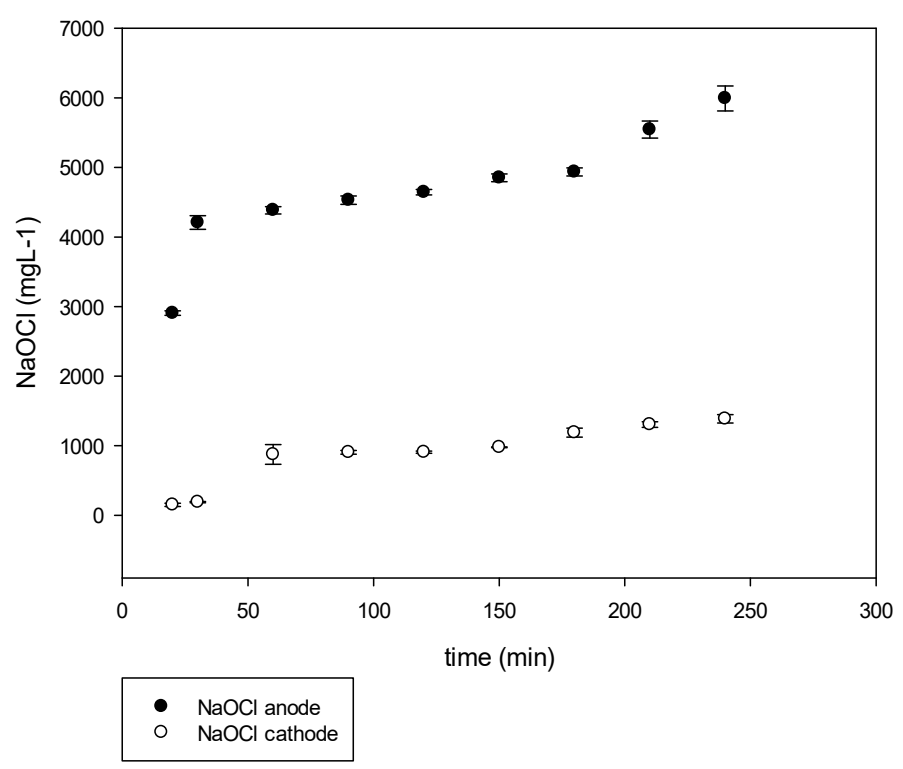

Figure 9. $\mathrm{NaOCl}$ production at anode and cathode in bubbling and recirculation configuration.

\subsection{Disinfection Capability}

According to the definition of a disinfectant, it will decrease microbial counts in a surface by at least five Log cycles in a given time. Results of the disinfection effectiveness of the produced $\mathrm{NaOCl}$ from the brine solution by the last configuration, was tested by the microbial challenge method against five bacterial strains isolated from the processing plant. The bacterial strains included a Gram-negative strain from the coliform group, two staphylococci strains, and two other Gram-positive strains. All strains tested showed a reduction of more than five Log cycles (initial count $1 \times 10^{7}$, final count less than $1 \times 10^{2} \mathrm{CFU} \mathrm{mL}{ }^{-1}$ ), or more than $99.999 \%$ reduction in microbial load. In order to assess the disinfection effectiveness under working conditions, $\mathrm{NaOCl}$ was tested for reduction of microbial counts in surfaces at the processing plant and compared to a commercial product (Cloralex, Nuevo León, Mexico). The $\mathrm{NaOCl}$ from the brine solution showed a reduction of $1.88 \pm 0.34 \mathrm{Log}$ or $98.41 \%$ (average initial count $1.5 \times 10^{3} \mathrm{Log} \mathrm{CFU} \mathrm{mL} \mathrm{mL}^{-1}$ ) in aerobic mesophilic count, while the commercial product achieved a reduction of $1.38 \pm 0.03 \mathrm{Log}$ reduction or $95.88 \%$ (average initial count $2.4 \times 10^{2} \mathrm{Log}$ CFU mL ${ }^{-1}, 98.41 \%$ ). Regarding total coliforms and E. coli reduction, initial numbers were on the range of less than $10 \mathrm{CFU} \mathrm{cm} \mathrm{cm}^{-2}$ to $50 \mathrm{CFU} \mathrm{cm} \mathrm{cm}^{-2}$; therefore, calculation of percentage of reduction for those microbial groups was not possible.

\subsection{Preliminary Economic Evaluation}

Commercial chlorine is mainly manufactured in three different ways. From the production process, several very useful byproducts are also obtained. Chlorine is produced by the electrolysis of sodium chloride (common salt). In addition to chlorine in the gaseous state, hydrogen and a sodium hydroxide solution were obtained. The cost of current technology varies depending on the system size. We made a projection in terms of the local costs of electricity, labor, chemicals used, and other elements which may be cheaper compared to other countries. The commercial price of the $\mathrm{NaOCl}$ is around $\$ 0.5 / \mathrm{L}$, plus the commercialization costs, transportation, and storage hazard, compared to an on-site generation system that will avoid many costs associated. The $\mathrm{NaOCl}$ obtained by our process presents a cost of $\$ 0.19 / \mathrm{L}$ including operational and maintenance costs. 
The costs for implementing the production train utilizing an on-site chlorine generator were also obtained. The relative comparison capital and operational and maintenance costs expressed in $\mathrm{m}^{3}$ of

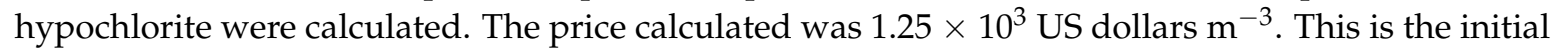
investment for the technology suggested for on-site production of hypochlorite, making possible the re-use of spent brines, minimizing the environmental impact of the brine generation and water contamination.

Therefore, the membrane technique, which has been labeled as the best available technology for chlor-alkali production, is the best performing technology industrially implemented.

\section{Discussion}

Brine conditioning is a fundamental step for the chlor-alkali process. It requires sodium chloride as an aqueous solution with certain quality requirements, which can vary as a function of the electrolytic technology evaluated [26]. In general, both ions cause physical disruption. Calcium forms insoluble compounds with hydroxide, silicate, aluminate, and other compounds; which deposit in the cathode layer of the membrane. This phenomena current causes efficiency reductions as low as $85 \%$ [21].

For proper operation of the EC cell, a primary treatment system was considered. In the first stage, impurity precipitation is needed. Following this process, an ion exchange resin can be used for the total treatment. In the chlor-alkali industry it is common to implement a primary precipitation with sodium carbonate and sodium hydroxide to mainly remove calcium and magnesium by the precipitation of the carbonates and hydroxides. Finally, the brine was purified using a cation exchange resin. Excess of reagent is needed to optimize the process. The concentrations commonly reported comprised between 0.1 and $0.5 \mathrm{~g} \mathrm{~L}^{-1} \mathrm{NaOH}$ and 0.3 and $1.5 \mathrm{~g} \mathrm{~L}^{-1} \mathrm{Na}_{2} \mathrm{CO}_{3}$ [27]. In this work, the best process to treat the spent brine, reducing the carbonate and noncarbonate hardness by $99.46 \%$, was the soda-ash one (1.03 $\mathrm{g} \mathrm{NaOH}$ and $2.042 \mathrm{~g} \mathrm{Na}_{2} \mathrm{CO}_{3}$ for $10 \mathrm{~L}$ of brine). The addition of chemicals is an important factor for considering the effectiveness of the process. Previous research works, recommend sequential additions, meanwhile others recommend addition of the reagents together [27]. For each application in particular, the design of the effective purification treatment by precipitation requires optimization where the amount of reactant is varied, as well as other major variables such as the addition order and temperature of the process.

The PCcell was designed to perform two chamber electrolysis experiments; the anolyte and catholyte are filled with the $\mathrm{NaCl}$ solution. For initial screening, it was necessary to follow the electrolysis reactions performed, as well as hypochlorite production. The saturated brine solution was channeled to both the anodic compartment and the cathodic compartment. Some water permeated through the membrane and entered the cathode compartment during the electrolysis. Chlorine gas was formed in the anode compartment. In the cathode compartment, hydrogen was released from the electrolysis of water (Equations (1) and (2)). Then, the hydroxyl ions combined with the sodium that permeates through the membrane regularly, if there was no sodium depletion to form sodium hydroxide.

$$
\begin{gathered}
\text { Anode : } 2 \mathrm{Cl}^{-}{ }_{(\mathrm{aq})} \rightarrow \mathrm{Cl}_{2(\mathrm{~g})} \uparrow+2 \mathrm{e}^{-} \\
\text {Cathode : } 2 \mathrm{H}_{2} \mathrm{O}_{(\mathrm{l})}+2 \mathrm{e}^{-} \rightarrow \mathrm{H}_{2(\mathrm{~g})} \uparrow+2 \mathrm{OH}^{-}{ }_{(\mathrm{aq})}
\end{gathered}
$$

Theoretically, saturated $\mathrm{NaCl}$ solutions should be fed to the anode compartment to assure high coverage of chloride ions at the surface of the electrode [21]. Pure $\mathrm{NaCl}$ was used for these assays (Figure 4). It is clear that salt concentration has an appreciable effect on voltage, such as operational time. The highest voltage was reached at a $\mathrm{NaCl}$ concentration of $20 \%$ and an operation time of $120 \mathrm{~min}$. The dependence of time in operational parameters was evidenced and the hypochlorite generation was followed in terms of salt concentration and time (Figure 5). When using membrane cells, the feed brine concentration should be between $170 \mathrm{~g} \mathrm{~L}^{-1}$ to $300 \mathrm{~g} \mathrm{~L}^{-1}$ [28]. These studies ranged from the regular salt concentration registered in the brine effluent $(5 \%)$ to the highest recommended by the cell manufacturer 
$(30 \%)$. It is noticeable an increase in hypochlorite concentration when high salt concentration was used. At $60 \mathrm{~min}$ a stationary state was approached. A maximum of $6000 \mathrm{mg} \mathrm{L}^{-1}$ was attained at that time using a $15 \%$ salt solution. Regarding low $\mathrm{NaCl}$ concentration (5\%), hypochlorite production reduced significantly, as low as $3000 \mathrm{mg} \mathrm{L}^{-1}$. Both values are in the range of the reported hypochlorite production using commercial cells (Table 1).

Table 1. Comparison among average rate of hypochlorite production as a function on concentration.

\begin{tabular}{|c|c|c|c|c|c|}
\hline \multirow[t]{2}{*}{ Trademark } & \multirow[t]{2}{*}{ Model } & \multicolumn{2}{|c|}{$\begin{array}{c}\text { CONCENTRATION } \\
\left(\mathrm{g} \mathrm{Cl}_{2} / \mathrm{L}\right)\end{array}$} & \multicolumn{2}{|c|}{$\operatorname{Rate}^{1}\left(\mathrm{~g} \mathrm{Cl}_{2} / \mathrm{Ah}\right)$} \\
\hline & & Theoretical & Experimental & Theoretical & Experimental \\
\hline \multirow{3}{*}{ Sanilec } & 2 & $5-6$ & fulfills & 1.05 & 1.02 \\
\hline & 6 & $5-6$ & fulfills & 1.90 & 2.22 \\
\hline & Mini & $5-6$ & fulfills & 2.06 & 1.09 \\
\hline \multirow{3}{*}{ Dipcell } & $\mathrm{A}$ & $5-6$ & fulfills & 1.80 & 1.82 \\
\hline & $\mathrm{B}$ & $5-6$ & fulfills & 1.42 & 1.56 \\
\hline & $\mathrm{C}$ & $5-6$ & fulfills & 1.64 & 1.74 \\
\hline Clorid & L-30 & 10 & does not fulfill ${ }^{2}$ & 1.15 & 0.78 \\
\hline \multirow{2}{*}{ Aquachlor } & AC-5 & $5-6$ & fulfills & 1.0 & 1.75 \\
\hline & AC -25 & $5-6$ & fulfills & 1.25 & 1.64 \\
\hline \multirow{3}{*}{ Yacu } & YECl-25 & $5-6$ & fulfills & 1.67 & 2.10 \\
\hline & YECl-15 & $5-6$ & fulfills & 1.50 & 1.71 \\
\hline & YECl-7 & $5-6$ & fulfills & 1.40 & 1.86 \\
\hline
\end{tabular}

${ }^{1}$ Rate for free-chlorine concentration 5-6 g/L, but cell Clorid L-30; ${ }^{2}$ Maxima free-chlorine concentration reached: $6.91 \mathrm{~g} / \mathrm{L}$.

As it is widely reported, the chemistry of $\mathrm{NaOCl}$ solutions is dependent on $\mathrm{pH}$ and electrochemical potential. The following equilibria are reported in water (3) and (4)

$$
\begin{gathered}
\mathrm{Cl}_{2(\mathrm{~g})}+\mathrm{H}_{2} \mathrm{O}_{(\mathrm{l})} \rightarrow \mathrm{HClO}_{(\mathrm{aq})}+\mathrm{H}^{+}{ }_{(\mathrm{aq})}+\mathrm{Cl}^{-}(\mathrm{aq}) \mathrm{pKa}<2 \text { at } 25{ }^{\circ} \mathrm{C} \\
\mathrm{HClO}_{(\mathrm{ac})} \rightarrow \mathrm{H}^{+}{ }_{(\mathrm{ac})}+\mathrm{OCl}^{-}{ }_{(\mathrm{ac})} \mathrm{pKa}=7.5 \text { at } 25{ }^{\circ} \mathrm{C}
\end{gathered}
$$

In the chlor-alkali process, free available chlorine is defined as the sum of $\mathrm{Cl}_{2}(\mathrm{aq}), \mathrm{HClO}$, and $\mathrm{OCl}^{-}$ concentrations and it is a measure of the amount of chlorine species that can oxidize any chemical compound. The acidic conditions in the anolyte are also required $(\mathrm{pH}<2)$ to minimize the formation of chlorate [26,29]. Also, the efficiency on the reaction rate of water oxidation is achieved at a low $\mathrm{pH}$ value. The $\mathrm{pH}$ was measured at each point of the process; in the anolyte, the $\mathrm{pH}$ value was reported from 2 to 3 and in the catholyte from 10 to 11 .

Current density is the most remarkable parameter of cell voltage, such as it was previously reported by other authors [29]. They also reported that the higher the current density and the anolyte $\mathrm{pH}$, the higher the cell voltage. In general, the cell voltage increases with current density and electrode distance. In our study both current density and the cell voltage increased linearly. Figures 5 and 6 establish that the chlorine generation reaction is dominant at intermediate and high current densities. Current densities using the cell tested were lower than the reported for commercial processes, such as Nafion (4-6 kA m $\left.{ }^{-2}\right)$, Aciplex (4-5 $\left.\mathrm{kA} \mathrm{m}^{-2}\right)$, and Flemion $\left(6 \mathrm{kA} \mathrm{m}^{-2}\right)$ [21].

The combination of bubbling and recirculation was the most effective process to obtain a higher concentration of $\mathrm{NaOCl}\left(7400 \mathrm{mg} \mathrm{L}^{-1}\right)$ from recovered and treated spent brine $(\mathrm{NaCl}, 5 \%)$. The cooling step (Figure 2c) allowed the removal of most of the water vapors and concentrated chlorine in the solution. Solubility is a function of temperature, and for gases, cooling increases their solubility in a liquid. The success of the cooling step in removing water and increase the solubility depends on the temperature differences among the cooling bath and the temperature of the water vapor stream. 
Many production plants implement this methodology. They used a chiller in a second stage to reduce the stream temperature for $\mathrm{NaOCl}$ production [21].

There are few reports on wastewater reuse with a high $\mathrm{NaCl}$ content for hypochlorite production. In our process, a brine that contaminates the environment is reused so we are reducing the cost of $\mathrm{NaCl}$. A fundamental parameter is initial $\mathrm{NaCl}$, followed by the interferences produced by hardness. As a comparison to our process, Gratacós in Tecnoaqua (2014) reported a maximum of $12.5 \%$ hypochlorite produced in an operation where calcium and magnesium are absent; starting from a $26 \% \mathrm{NaCl}$ solution [15]. Braduzzaman and coworkers (2009) evaluated the hypochlorite production from brine. They presented a reuse strategy for reverse osmosis concentrate produced by an integrated membrane system from a wastewater reclamation facility. They evaluated electro-chlorination for on-site chlorine generation, producing a $0.6 \%$ hypochlorite solution from the reconstituted brine. They prepared a $26 \%$ salt solution and mix it with 10 parts of the brine per part of salt solution. The EC procedure was preceded by a softening process where cation exchange resin was used to reduce hardness [30]. The results attained concerning the initial concentration in the real brine are thus superior to the ones attained by these authors. Quin et al. described a pilot scale sodium hypochlorite continuous generator for cleaning in place in food industry. They parted from $3-4 \% \mathrm{NaCl}$, and operated the cell at $3-5 \mathrm{~mL} \mathrm{~s}^{-1}$ flow rate, $3.85 \mathrm{~V}$ in voltage, $0.3 \mathrm{~A} \mathrm{~cm}^{-2}$ of current density, and temperature less than $30{ }^{\circ} \mathrm{C}$ and produced $200 \mathrm{mg} \mathrm{L}^{-1}$ of free chlorine [31]. The system was started operating at the current of $24 \mathrm{~A}$ and operated for $6 \mathrm{~h}$. In our case we produce a higher concentration of $\mathrm{NaOCl}$ because we recirculate the treated brine until we reached the targeted sodium hypochlorite concentration. For that reason, the current density was lower than other studies. We maintain a high concentration of ions which required less current draw.

\section{Conclusions}

The research presented in this paper has successfully demonstrated that water softener spent brines can be reused to successfully generate chlorine and sodium hydroxide. The spent brine rich in precipitable ions and high alkalinity was successfully treated to prevent electrolysis fouling. Two different chemical precipitation processes were tested-lime-soda ash and sodium hydroxide-soda ash softening - the last one being the most effective as total hardness was decreased by $99.98 \%$. The hypochlorite production for the bubbling configuration produced a total amount of $1 \mathrm{~g} \mathrm{~A}^{-1} \mathrm{~h}^{-1}$. By incorporating a chlorine gas trap in order to increase $\mathrm{OCl}^{-}$concentration, a maximum of $7400 \mathrm{mg} \mathrm{L}^{-1} \mathrm{NaOCl}$ was achieved. Finally, biocidal activity was tested following sanitation protocols ( $\mathrm{NaOCl}$ dilution level) on workbenches and bacterial cultures and a decrease in bacterial count of at least 5 logs.

Author Contributions: D.S.-A.: Contributed to the conceptualization, methodology, validation, investigation, and original draft preparation. N.O.-C.: Contributed to the lab and industrial scale, electrolytic cells implementation, to the experimental design, and original draft preparation. B.A.R.-G.: Carried out physicochemical parameters in water, evaluation of the softening processes; and contributed to funding acquisition. L.B.-C.: Contributed to formal analysis, investigation, and writing. E.J.P.-D.: Performed laboratory experiments for electrolysis. G.V.N.-M.: Made all microbiological studies. L.A.S.-S.: Contributed to data analysis and editing. S.O.-H.: Made all industrial tests. G.C.-F.: Coordinated all project industrial acquisitions. G.G.-S.: Contributed to the conceptualization, methodology, and to funding acquisition.

Funding: This research was funded by the CONACYT project CB-2012-01-183970 and project PEI-221891.

Acknowledgments: The authors appreciated BAFAR support.

Conflicts of Interest: The authors declare no conflicts of interest. 


\section{References}

1. Morita, C.; Sano, K.; Morimatsu, S.; Kiura, H.; Goto, T.; Kohno, T.; Hong, W.; Miyoshi, H.; Iwasawa, A.; Nakamura, Y.; et al. Disinfection potential of electrolyzed solutions containing sodium chloride at low concentrations. J. Virol. Methods 2000, 85, 163-174. [CrossRef]

2. Giaouris, E.; Heir, E.; Hébraud, M.; Chorianopoulos, N.; Langsrud, S.; Møretrø, T.; Habimana, O.; Desvaux, M.; Renier, S.; Nychas, G.J. Attachment and biofilm formation by foodborne bacteria in meat processing environments: Causes, implications, role of bacterial interactions and control by alternative novel methods. Meat Sci. 2014, 97, 298-309. [CrossRef] [PubMed]

3. Ganesh Kumar, C.; Anand, S.K. Significance of microbial biofilms in food industry: A review. Int. J. Food Microbiol. 1998, 42, 9-27. [CrossRef]

4. Flint, S.H.; Bremer, P.J.; Brooks, J.D. Biofilms in dairy manufacturing plant-description, current concerns and methods of control. Biofouling 1997, 11, 81-97. [CrossRef]

5. Banwart, G.J. Basic Food Microbiology; Chapman \& Hall: New York, NY, USA, 1989. [CrossRef]

6. De los Santos Villamil, A.A.; Hernández Anguiano, A.M.; Eslava Campos, C.A.; Landa Salgado, P.; Mora Aguilera, G.; Luchansky, J.B. Producción de biopelículas y resistencia a desinfectantes en cepas de salmonella aisladas de nopal, agua y suelo. Revista Mexicana de Ciencias Agrícolas 2012, 3, 1063-1074. [CrossRef]

7. Antoniou, K.; Frank, J.F. Removal of pseudomonas putida biofilm and associated extracellular polymeric substances from stainless steel by alkali cleaning. J. Food Protect. 2005, 68, 277-281. [CrossRef]

8. Corcoran, M.; Morris, D.; De Lappe, N.; O'Connor, J.; Lalor, P.; Dockery, P.; Cormicana, M. Commonly used disinfectants fail to eradicate Salmonella enterica biofilms from food contact surface materials. Appl. Environ. Microbiol. 2014, 80, 1507-1514. [CrossRef] [PubMed]

9. Sharma, M.; Ryu, J.H.; Beuchat, L. Inactivation of Escherichia coli O157:H7 in biofilm on stainless steel by treatment with an alkaline cleaner and a bacteriophage. J. Appl. Microbiol. 2005, 99, 449-459. [CrossRef] [PubMed]

10. Arizcun, C.; Vasseur, C.; Labadie, J.C. Effect of several decontamination procedures on listeria monocytogenes growing in biofilms. J. Food Protect. 1998, 61, 731-734. [CrossRef]

11. Stucki, S.; Kötz, R.; Carcer, B.; Suter, W. Electrochemical waste water treatment using high overvoltage anodes part II: Anode performance and applications. J. Appl. Electrochem. 1991, 21, 99-104. [CrossRef]

12. Kaczur, J.J.; Lubie, D.B.; Cudworth, E.M.; Clements, C.W.; Nelson, M.E. Process for the On-Site Production of Chlorine and High Strength Sodium Hypochlorite. U.S. Patent 7,931,795B2, 26 April 2011.

13. Rojas, R.; Guevara, S. Celdas Electrolíticas Para La Producción In Situ De Hipoclorito de Sodio. OPS. 2000. Available online: http:/ / www.bvsde.paho.org/eswww/proyecto/repidisc/publica/hdt/hdt78/hdt78.html (accessed on 28 August 2017).

14. Asokan, K.; Subramanian, K. Design of a tank electrolyser for in-situ generation of NaOCl. In Proceedings of the World Congress on Engineering and Computer Science, WCECS 2009, San Francisco, CA, USA, 20-22 October 2009; Volume I, pp. 139-142. Available online: http://www.iaeng.org/publication/ WCECS2009/WCECS2009_pp139-142.pdf (accessed on 28 August 2017).

15. Gratacós, J.M. Generadores de cloro por electrólisis de salmuera con tecnología de célula con membrana. Tecnoaqua 2014, 5, 109-114.

16. Madaeni, S.S.; Kazemi, V. Treatment of saturated brine in chlor-alkali process using membranes. Sep. Purif. Technol. 2008, 61, 68-74. [CrossRef]

17. McRae, W.A. Process and Apparatus for Controlling Impurities and Pollution from Membrane Chlor-Alkali Cells. U.S. Patent 4,242,185A, 30 September 1980.

18. Kapp, E.M. The Precipitation of Calcium and Magnesium from Sea Water by Sodium Hydroxide. Biol Bull. 1928, 55, 453-458. [CrossRef]

19. Karlsson, R.K.B.; Cornell, A. Selectivity between oxygen and chlorine evolution in the chlor-alkali and chlorate processes. Chem. Rev. 2016, 116, 2982-3028. [CrossRef] [PubMed]

20. Sánchez-Sánchez, C.M.; Expósito, E.; Frias-Ferrer, A.; González-García, J.; Montiel, V.; Aldaz, A. Chlor-Alkali Industry: A laboratory Scale Approach. J. Chem. Ed. 2004, 81, 698-700. [CrossRef] 
21. O’Brien, T.F.; Bommaraju, T.V.; Hine, F. Handbook of Chlor-Alkali Technology; Springer: New York, NY, USA, 2005; Volume I. Available online: https:/ /link.springer.com/content/pdf/10.1007\%2Fb113786.pdf (accessed on 25 November 2017).

22. Moorhouse, J. Modern Chlor-Alkali Technology; Wiley-Blackwell: London, UK, 2001; Volume 8. Available online: http:/ / www.wiley.com/WileyCDA/WileyTitle/productCd-0632055596,subjectCd-CH31. html (accessed on 25 November 2017).

23. Aragon, P.J. Chlorination and pH Control System. U.S. Patent 4,767,511A, 30 August 1988.

24. Lynn, S.; Sciamanna, S.F.; Sciamanna, A.F. Chlorine Generator. U.S. Patent 5,362,368A, 8 November 1994.

25. Brinkmann, T.; Giner Santoja, G.; Schorcht, F.; Roudier, S.; Delgado Sancho, L. Best Available Techniques (BAT) Reference Document for the Production of Chlor-alkali EUR 26844 EN- Joint Research Centre; Institute for Prospective Technological Studies: Luxembourg, 2014. [CrossRef]

26. Garcia-Herrero, I.; Margallo, M.; Onandía, R.; Aldaco, R.; Irabien, A. Life Cycle Assessment model for the chlor-alkali process: A comprehensive review of resources and available technologies. Sustain. Prod. Consump. 2017, 12, 44-58. [CrossRef]

27. Integrated Pollution Prevention Control (IPPC), Best Available Techniques (BAT) Reference Document for the Production of Chlor-Alkali, Draft. December 2011, Seville, Spain. Available online: http:/ / eippcb.jrc.ec. europa.eu/reference/BREF/CAK_BREF_102014.pdf (accessed on 28 August 2017).

28. Casas Garriga, S. Valorization of Brines in Chlor-Alkali Industry. Integration of Precipitation and Membrane Processes. Ph.D. Thesis, Univesitat Politecnica de Catalunya, Barcelona, Spain, 2011.

29. Jalali, A.A.; Mohammadi, F.; Ashrafizadeh, S.N. Effects of process conditions on cell voltage, current efficiency and voltage balance of a chlor-alkali membrane cell. Desalination 2009, 237, 126-139. [CrossRef]

30. Badruzzaman, M.; Oppenheimer, J.; Adham, S.; Kumar, M. Innovative beneficial reuse of reverse osmosis concentrate using bipolar membrane electrodialysis and electrochlorination processes. J. Membr. Sci. 2009, 326, 392-399. [CrossRef]

31. Qin, G.F.; Li, Z.Y.; Chen, X.D.; Russell, A.B. An experimental study of an $\mathrm{NaOCl}$ generator for anti-microbial applications in the food industry. J. Food Eng. 2002, 54, 111-118. [CrossRef]

(C) 2018 by the authors. Licensee MDPI, Basel, Switzerland. This article is an open access article distributed under the terms and conditions of the Creative Commons Attribution (CC BY) license (http:/ / creativecommons.org/licenses/by/4.0/). 